\title{
Article
}

\section{Optimal Design Approach Applied to Headspace GC for the Monitoring of Diacetyl Concentration, Spectrophotometric Assessment of Phenolic Compounds and Antioxidant Potential in Different Fermentation Processes of Barley}

\author{
Fouad El Mansouri ${ }^{1, *(\mathbb{D}}$, Hammadi El Farissi ${ }^{2}\left(\mathbb{D}\right.$, Francesco Cacciola ${ }^{3, *(\mathbb{D}}$, Badr Bouhcain $^{4}(\mathbb{D}$, \\ Joaquim C. G. Esteves da Silva ${ }^{5}$, Miguel Palma Lovillo ${ }^{6}$ id and Jamal Brigui ${ }^{1}$ \\ 1 Laboratory of Chemical Engineering and Valorization of Resources, Department of Chemistry, \\ Faculty of Sciences and Technology, Abdelmalek Essaâdi University, Tangier 90000, Morocco; \\ j.brigui@fstt.ac.ma \\ 2 Laboratory of Environment and Applied Chemistry of the Natural Resources and Processes, \\ Department of Chemistry, Faculty of Sciences, Mohamed First University, Oujda 60000, Morocco; \\ hammadi.elfarissi@taalim.ma \\ 3 Department of Biomedical, Dental, Morphological and Functional Imaging Sciences, University of Messina, \\ 98125 Messina, Italy \\ 4 Laboratory of Research and Development in Engineering Sciences, Faculty of Science and Technology of Al \\ Hoceima, Abdelmalek Essaâdi University, Tetouan 93000, Morocco; badr.bouhcain@etu.uae.ac.ma \\ check for \\ updates \\ Citation: Mansouri, F.E.; Farissi, H.E. \\ Cacciola, F.; Bouhcain, B.; Silva, \\ J.C.G.E.d.; Lovillo, M.P.; Brigui, J. \\ Optimal Design Approach Applied \\ Chemistry Research Unit (CIQUP), DGAOT, Faculty of Sciences of University of Porto, R. Campo Alegre 697, \\ 4169-007 Porto, Portugal; jcsilva@fc.up.pt \\ 6 Department of Analytical Chemistry, Faculty of Sciences, Instituto de Investigación Vitivinícola y \\ Agroalimentaria (IVAGRO), University of Cadiz, Campus del Rio San Pedro, 11510 Puerto Real, Spain; \\ miguel.palma@uca.es \\ * Correspondence: fouad.elmansouri@etu.uae.ac.ma (F.E.M.); cacciolaf@unime.it (F.C.); \\ Tel.: +212-662-102-847 (F.E.M.); +39-090-676-6570 (F.C.)
} to Headspace GC for the Monitoring of Diacetyl Concentration, Spectrophotometric Assessment of Phenolic Compounds and Antioxidant Potential in Different Fermentation Processes of Barley. Appl. Sci. 2022, 12, 37. https:// doi.org/10.3390/app12010037

Academic Editors: Roberto Beghi and Valentina Giovenzana

Received: 3 November 2021 Accepted: 13 December 2021 Published: 21 December 2021

Publisher's Note: MDPI stays neutral with regard to jurisdictional claims in published maps and institutional affiliations.

Copyright: (C) 2021 by the authors. Licensee MDPI, Basel, Switzerland. This article is an open access article distributed under the terms and conditions of the Creative Commons Attribution (CC BY) license (https:// creativecommons.org/licenses/by/ $4.0 /)$.
Abstract: The present study aimed to validate a control method on the gas chromatography system (GC) based on the experimental design strategy, to examine the changes and correlation between the fermentation process and the quality of alcoholic and non-alcoholic beer product, especially the formation of diacetyl. On the other hand, spectrophotometric methods were applied to the determination of polyphenols content and the potential antioxidant activity of beer during different fermentation processes. with this aim, three modes of barley fermentation were used, specifically classical fermentation, stopped fermentation and thermal process. The results showed that the different fermentation modes had a major impact on diacetyl production. The highest concentration was obtained using stopped fermentation $0.36 \mathrm{mg} / \mathrm{L}$, the lowest concentration value $0.07 \mathrm{mg} / \mathrm{L}$ was detected using the thermal process. Monitoring the increase of oxygen concentration between fermentation, filtration, and filling of the final product $(32,107,130 \mathrm{ppm}$, respectively) has a significant impact on the concentration of diacetyl. The obtained results of spectrophotometric analysis showed that the total antioxidant activity changed during beer fermentation process and demonstrate that the extend of the antioxidant activity was very much dependent on the total polyphenolic content with a higher value in Hopped wort $\left(13.41 \%, 65 \mathrm{mg}\right.$ GAE $100 \mathrm{~mL}^{-1}, 28 \mathrm{mg} \mathrm{CE} 100 \mathrm{~mL}^{-1}$ ) for antioxidant potential, total phenolic content, and total flavonoids content, respectively, whereas the lowest values was detected in Non-alcoholic beer using thermal process $(7.24 \%, 35 \mathrm{mg}$ GAE

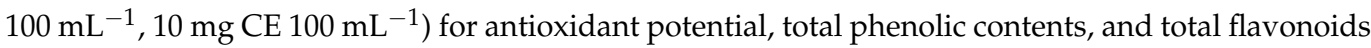
contents, respectively. Based on the results achieved, we reveal the impact of the fermentation process on the nutritional value of the final product.

Keywords: experimental design; headspace GC; diacetyl; fermentation; barley; spectrophotometric; antioxidant activity; TPC; TFC 


\section{Introduction}

Beer is one of the first-born and popular fermented drinks in mankind's history, The process by which beer is brewed has not changed significantly since its discovery thousands of years ago and the production of this beverage can be considered as very traditional and remain still the same, without important variations ever since its earliest origin. Generally, the process is based on natural enzymatic activity happening throughout the malting of grain, mashing of grist and fermentation of wort [1]. Beer is a complicated combination of ingredients, fermented from raw materials including water, yeast, malt and hops, and comprises a wide range of several chemical components that may react and interact at all stages of the brewing process [2]. Various groups of compounds have been shown to play an important role in the flavor characteristics [3], e.g., esters, higher alcohols, aldehydes, ketones, organic acids), which contribute to the last sensorial character of beer [4] Some of these by-products are unsuitable because they impart beer off-flavors/aromas [5]. Particularly interesting topics are the reduction of diacetyl, dimethyl sulfide (DMS) or hydrogen sulfide and an enhanced production of sulfur dioxide or esters [6]. They are originated from two amino acids namely valine and leucine, and are responsible for toffee, butterscotch, honey and vanilla-like off-flavors when they are present at concentrations higher than their threshold values $(>0.1-0.4 \mathrm{mg} / \mathrm{L})[7,8]$. In addition, they may play the most important role in the final flavor [9].

The Diacetyl (2,3 butanedione), is a volatile $\alpha$-diketone, produced naturally in fermented products and as a yeast metabolism product during fermentation by yeast and bacteria. Remaining to its characteristic butter such as aroma, diacetyl has been widely used as a synthetic butter flavoring agent in food products [10] such as microwave popcorn [11], confectionery, baked goods [12] and in flavored electronic cigarette liquids [13,14]. On the other hand, Dimethyl sulfide (DMS), as the majority of unpleasant sulfury flavors, originates mainly from wort and hops, however, another possible origin is dimethyl sulfoxide (DMSO) by yeast during fermentation or wort-spoilage bacteria [15], DMS may significantly affect the aroma of beer and may lead to undesirable flavor impressions such as cooked cabbage or sweet-corn $[7,15]$. Despite the increasing recognition of diacetyl toxicity, various studies have shown shedding of epidermal growth factor receptor (EGFR) ligand amphiregulin following the exposure to diacetyl $[16,17]$ and increased secretion of inflammatory cytokines $[17,18]$ and the augmentation of reactive oxygen species (ROS) production, reduced antioxidant defenses [19,20], epithelial injury [21] and protein damage [22], development of bronchiolitis obliterans (BO), a severe and irreversible lung disease [12,23-25]. Furthermore, DMS is recognized to cause toxic central nervous system (CNS) effects, including diaphragmatic paralysis and coma, accompanied by asphyxia because of oxygen depletion at very high concentrations of DMS. Coroners from Japan and Russia $[26,27]$ report lung edema and visceral hyperemia in victims that have succumbed to paper-mill by product exposures rich in DMS (up to $80 \%$ ).

During the first four days of fermentation the conversion into the vicinal diketones, such as diacetyl and 2,3-pentanedione, is the highest, after which the formation of other products from these ketones are superior. So, there is a reduction of the concentrations of diacetyl and 2,3-pentanedione during fermentation and lagering. It is important to achieve low concentrations of these compounds in the final product because they cause an off flavor. Several reasons (e.g., fermentation, temperature, aeration) can be the cause of high concentrations. Therefore, during the production of beer it is important to maintain the optimum adjustments to prevent off- flavors caused by diacetyl and DMS. Since the determination described here concerns relatively volatile compounds it is possible to apply headspace injection, meaning that part of the vapor above the beer sample is injected after equilibration at a fixed temperature.

The overall objective of this study was designed to develop a simple and rapid method of control using GC based on strategy of the experimental design to check out the effect of oxygen on the chemical breakdown of Diacetyl during fermentation processes, so as to achieve the improvement of the technological control of the flavor profile, in the production 
of the flavor active compounds. On the other hand, the application of a spectrophotometric methods to evaluate the total phenolic, flavonoids content and the antioxidant capacity of each beer type to evaluate the impact of fermentation processing on the nutritional value on the final product.

\section{Materials and Methods}

\subsection{Materials}

Barley malt was subjected to three fermentation methods, namely normal fermentation, arrested fermentation, and fermentation coupled with a thermal process. Beer samples from different fermentation methods were analyzed during the production of alcoholic and alcohol-free beer, Saccharomyces cerevisiae is the yeast utilized during the different process of fermentation. The yeast was propagated from a freezer stock maintained at $-150{ }^{\circ} \mathrm{C}$.

\subsection{Stopped Fermentation Methods}

Fermentation can be stopped by removing the yeast cells or by rapidly cooling the fermenting must. This technique requires musts with low concentrations of fermentable carbohydrates. The fermentation stage is conducted at low temperature, about $2-3{ }^{\circ} \mathrm{C}$, with a contact time of about $200 \mathrm{~h}$. During fermentation, the must is not aerated to prevent yeast reproduction and to prolong the lag phase during which the yeast consumes and metabolizes but does not propagate or produce ethanol.

\subsection{Thermal Process}

The beer is degassed and subsequently preheated in a plate heat exchanger. The beer is fed into the stripping section of a rectification column. The product flows through the column at a temperature between $43{ }^{\circ} \mathrm{C}$ and $48^{\circ} \mathrm{C}$. In countercurrent, the product meets rising vapors that cause selective separation of the alcohol from the product. The alcoholfree beer is then introduced into an evaporator from the bottom of the column. In the evaporator, the vapors necessary for the rectification process are produced and redirected to the column. The completely dealcoholized product is pumped out of the plant after passing through a cooler [28].

\subsection{Chemicals}

GC parameter Chromatographic condition: The GC esters separation was performed using a DBWAX (Agilent Technologies, Stevens Creek Blvd., Santa Clara, CA, USA) Column with a capillarity of $(60 \mathrm{~m} \times 530 \mu \mathrm{m} \times 1 \mu \mathrm{m})$ nominal with a temperature max of $240{ }^{\circ} \mathrm{C}$ for the reference $50 \mathrm{~m} \times 530 \mu \mathrm{m} \times 1 \mu \mathrm{m}$ nominal temperature max of $320^{\circ} \mathrm{C}$. Column used for diacetyl is the DB5 (Agilent Technologies, Stevens Creek Blvd., Santa Clara, CA, USA) with a capillarity of $(60 \mathrm{~m} \times 530 \mu \mathrm{m} \times 1 \mu \mathrm{m})$ with a max temperature of $320^{\circ} \mathrm{C}$ for the reference the capillarity is $50 \mathrm{~m} \times 530 \mu \mathrm{m} \times 1 \mu \mathrm{m}$ with a max temperature of $320^{\circ} \mathrm{C}$. This difference in column type and the design of the apparatus may have led to variations in temperature and pressure, especially in the furnace, injectors, columns, and detectors, because of the method used. To create a reliable method, we used an experiment plan based on a matric that allowed us to determine the different settings and subsequently the injections.

\subsection{Concepts on Experimental Designs}

In the present study we conducted to develop a method for determining the parameters that affect the quality of beer taste, we took a reference sample with known concentrations and each time we change the data according to an experimental design to find the same concentrations as the reference.

The experimental designs make it possible to organize the trials that accompany scientific research or industrial studies in the best strategy, With the plans of experiments the maximum information are obtained with the minimum of experiments. In this context, we must follow mathematical rules and adopt a rigorous approach [29]. The factors considered in an experimental design are the input factors. 
The factorial experimental designs all use the following mathematical model that links the response $y$ to the factors $x_{1}, x_{2}, \ldots x$. This theoretical model is postulated a priori. This is a polynomial model (1).

$$
Y=a_{0}+a_{1} \cdot x_{1}+a_{2} \cdot x_{2}+\ldots \ldots \ldots \ldots+a_{n} \cdot x_{n} \quad \sum_{i . j=1 i \neq j \neq k}^{n} \text { aijk } x i \cdot x j \cdot x k+\cdots
$$

A response surface plan is a set of advanced techniques (experiment plan) that allow us to better understand and optimize the response. The response surface design methodology is often used to develop models following the determination of important factors using factorial designs, particularly if you suspect a curvature in the response surface [30].

Regarding the characteristics of the studied factors, the choice was based on a surface plan with three factors: Where $a_{0}, a_{1} \ldots$ Are the coefficients of the polynomial (2).

$$
Y=a_{0}+a_{1} \cdot x_{1}+a_{2} \cdot x_{2}+a_{3} \cdot x_{3}+a_{12} \cdot x_{1} \cdot x_{2}+a_{13} \cdot x_{1} \cdot x_{3}+a_{23} \cdot x_{2} \cdot x_{3}+a_{123} \cdot x_{1} \cdot x_{2} \cdot x_{3}
$$

The product terms of type for example aij.xi.xj correspond to interactions.

A final mandatory step before using the model in production will be to test by an experiment in the center of the experimental domain if the value predicted by the model is close to the experimental value [30].

\subsubsection{Methods}

Nemrodw

This software used for experimental designs allows the construction of classic experimental matrices, specific to the type of objective pursued: in this case it is a study in an experimental field (response surfaces).

Factors and Response

Three factors influence principally on the retention time of diacetyl during GC analysis.

- $\quad$ Oven temperature. (Measured by $\mathrm{x}_{1}$ in ${ }^{\circ} \mathrm{C}$ ).

- $\quad$ Intel Back Temperature. (Measured by $\mathrm{x}_{2}$ in ${ }^{\circ} \mathrm{C}$ ).

- Column pressure. (Measured by $x_{3}$ in ATM).

The response (y) quantified by the retention time of diacetyl corresponding to its concentration. The objective is to validate the values of the factors on the machine that allows us to have a better response.

\subsection{Qualitative and Quantitative Methods}

2.6.1. The Determination of Diacetyl and 2,3-Pentanedione in Packaged Beer Using Headspace Gas Chromatography

A- Internal standard stock solution

$150 \mu \mathrm{L}$ 2,3-hexanedione in $100 \mathrm{~mL}$ ethanol

Preparation: Pour about $90 \mathrm{~mL}$ cold $\left(0^{\circ} \mathrm{C}\right)$ ethanol in a $100 \mathrm{~mL}$ volumetric flask. Place the flask in a tray with melting ice. Add $150 \mu \mathrm{L}$ 2,3-hexanedione using a $250 \mu \mathrm{L}$ syringe. Make up to $100 \mathrm{~mL}$ at $0{ }^{\circ} \mathrm{C}$ with cold $\left(0^{\circ} \mathrm{C}\right)$ ethanol. Stability: In refrigerator 1 week.

B- Internal standard working solution

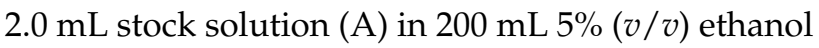

Preparation: Pour about $50 \mathrm{~mL}$ cold $\left(0{ }^{\circ} \mathrm{C}\right) 5 \%(v / v)$ ethanol/water in a $200 \mathrm{~mL}$ volumetric flask. Pipette $2.0 \mathrm{~mL}$ of the cold $\left(0^{\circ} \mathrm{C}\right)$ stock solution $(\mathrm{A})$ into the flask. Make up to $200 \mathrm{~mL}$ with cold $\left(0^{\circ} \mathrm{C}\right) 5 \%(v / v)$ ethanol/water and mix. Transfer the solution to the dispenser when used. Stability: In refrigerator 1 week. 
2.6.2. The Determination of Acetaldehyde, Dimethyl Sulfide, Esters, and Higher Alcohols by Gas Chromatography

X-Internal Standard Stock Solution

Preparation: Pour $50 \mathrm{~mL}$ ethanol in a $100 \mathrm{~mL}$ volumetric flask. Pipette $3.0 \mathrm{~mL}$ 4heptanon and $30.0 \mathrm{~mL}$ n-butanol into the flask. Make up to $100 \mathrm{~mL}$ with distilled-water and mix. Stability: In refrigerator $\left(0-10^{\circ} \mathrm{C}\right) 1$ month.

Y-Internal Standard Working Solution

Preparation: Pour $50.0 \mathrm{~mL}$ ethanol and about $400 \mathrm{~mL}$ distilled water in a $1000 \mathrm{~mL}$ volumetric flask. Pipette $20.0 \mathrm{~mL}$ of the stock solution (A) into the flask. Make up to 1000 $\mathrm{mL}$ with distilled water and mix. Transfer the solution to the bottle with dispenser when used. Stability: In refrigerator $\left(0-10^{\circ} \mathrm{C}\right) 1$ month.

The normal procedure for sample preparation is as follows: Slowly fill a $250 \mathrm{~mL}$ graduated measuring cylinder with the cold $\left(0-10{ }^{\circ} \mathrm{C}\right)$ beer sample. Remove the excess of beer and/or foam by using a waterjet suction pump to obtain $250 \mathrm{~mL}$. Pipette $2.0 \mathrm{~mL}$ (volumetric pipette or dispenser) of the internal standard working solution $\mathrm{B}$ and $\mathrm{D}$ into an infusion bottle. Immediately add the beer sample to the infusion bottle. Close with a screwcap and rubber septum and carefully mix. In this way the samples are prepared one by one. After a series of samples has been prepared, each infusion bottle should be kept closed for at least $5 \mathrm{~min}$ to prevent foaming over. Prepared samples can be stored in the refrigerator $\left(0-10^{\circ} \mathrm{C}\right)$ for 2 days.

Preparation: Pour about $50 \mathrm{~mL}$ of the $250 \mathrm{~mL}$ prepared sample (with internal standard) into another clean infusion bottle, close and place in a water bath of $40^{\circ} \mathrm{C}$, place a (vinylcovered) lead weight around the neck of the bottle to prevent floating, (Lead donut $50 \mathrm{~mm}$, Tamson 486K32 or order via GSC), pierce a disposable needle through the septum to prevent overpressure, after $30 \mathrm{~min}$ of conditioning inject about $0.5 \mathrm{~mL}$ of the headspace.

\subsubsection{Spectroscopic Analysis of Polyphenols}

The spectrophotometric analyses were performed using a UV-1601 spectrophotometer from Shimadzu (Duisburg, Germany) and were replicated three times for each extract or calibration point $(n=3)$.

\subsubsection{Determination of Total Phenolic Content (TPC)}

The total phenolic content was determined based on a spectrophotometric method using the Folin-Ciocalteu reagent according to the method of Signleton et al. (1999) [31]. This reagent leads to oxidizes the phenolic compounds, which turns the solution to blue. The TPC was quantified from a calibration curve prepared with gallic acid standard and expressed as mg of gallic acid equivalents (GAE) per $100 \mathrm{~mL}$ of sample $\left(\mathrm{mg} \mathrm{GAE} 100 \mathrm{~mL}^{-1}\right.$ ). The calibration curve was drawn, and the equation of linear regression was obtained:

$$
y=1.552 x+0.208, R^{2}=0.962
$$

\subsubsection{Determination of Flavonoid Content (TFC)}

Total flavonoid content was performed using the aluminum chloride $\left(\mathrm{AlCl}_{3}\right)$ based on the protocol described by Kim et al. (2003) [32]. The TFC in samples was quantified from a calibration curve prepared with Catechin standard and expressed as $\mathrm{mg}$ of catechin equivalents (CE) per $100 \mathrm{~mL}$ of sample (mg CE $\left.100 \mathrm{~mL}^{-1}\right)$. The calibration curve was drawn, and the equation of linear regression was obtained: $y=2.857 x+0.080, R^{2}=0.999$.

\subsubsection{Determination of Free Radical Scavenging Activity in Beer by DPPH}

Regarding the analyses and evaluation of the described methods, the results of the ruggedness test for determination of the conditions of the method, coefficients of variation and recommendations of some authors was elaborated a simple modification of the protocol 
for determination of antioxidant capacity using DPPH (2,2-diphenyl-1-picrylhydrazyl), a stable free radical in beer and beverages [33].

Preparation of Diluted sample. Dilute $13.3 \mathrm{~mL}$ of degassed beer with water to $100 \mathrm{~mL}$ at temperate to $20^{\circ} \mathrm{C}$, attemperate to $20^{\circ} \mathrm{C}$ in volumetric ask and the solution was vortexed thoroughly, $2.5 \mathrm{~mL}$ of diluted beer was added to $20 \mathrm{~mL}$ of ethanol and kept the mixture to stand $20 \mathrm{~min}$ at $20^{\circ} \mathrm{C}$, then fill up the volume to $25 \mathrm{~mL}$ with attemperated ethanol, the solution was homogenized rigorously, finally the mixture was transferred to a fluted filter, filtered, and stored at $20^{\circ} \mathrm{C}$ before using.

Diluted blank. Dilute $2.5 \mathrm{~mL}$ of water with ethanol in volumetric ask $25 \mathrm{~mL}$. Attemperate $20 \mathrm{~min}$ to $20^{\circ} \mathrm{C}$. The mixture could be filtered If is necessary through fluted filter.

Preparation of DPPH stock solution. $0.06 \mathrm{mM}$ of DPPH methanolic solution $(0.0024 \mathrm{~g}$ $\mathrm{DPPH} / 100 \mathrm{~mL}$ ethanol) Attemperate $20 \mathrm{~min}$ to $20^{\circ} \mathrm{C}$. The stock solution should be freshly used.

\section{Determination}

Sample. In a test tube, $1.5 \mathrm{~mL}$ of diluted sample was added to $1.5 \mathrm{~mL}$ of DPPH solution, the mixture was homogenized and incubated for $30 \mathrm{~min}$ in darkness at room temperature, the absorbance was measured at $517 \mathrm{~nm}$, against diluted blank.

Control. $1.5 \mathrm{~mL}$ of diluted blank was added to $1.5 \mathrm{~mL}$ of DPPH solution, vortexed thoroughly. In addition, kept in the dark for $30 \mathrm{~min}$, the absorbance was measured at 517 nm against diluted blank.

Calculation of the Results

DPPH scavenging activity was expressed as a percentage of free radical scavenging activity (FRSA) with DPPH or as \% inhibition of the free radical with DPPH according to the following formula:

$$
\% \mathrm{I}=\frac{\text { A control }- \text { A sample }}{\text { A control }} \times 100
$$

\section{Results and Discussion}

\subsection{Experimental Area}

The classical factors studied on the experimental design.

The obtained results (Tables 1-4) showed that after the application of the experimental design the optimal adjustment for determination of volatile components was based on three parameter values:

- $\quad$ Oven temperature $=70^{\circ} \mathrm{C}$

- $\quad 70^{\circ} \mathrm{C} \leq$ Intel Back Temperature $\leq 130{ }^{\circ} \mathrm{C}$

- $\quad 39 \mathrm{~atm} \leq$ Column Pressure $\leq 40 \mathrm{~atm}$

Table 1. The factors influenced on the retention time of diacetyl analyzed by experimental design.

\begin{tabular}{cccc}
\hline Experience & Factors & Centre & Variation Degree \\
\hline X1 & Oven temperature. & $100{ }^{\circ} \mathrm{C}$ & 30 \\
X2 & Intel Back Temperature. & $100{ }^{\circ} \mathrm{C}$ & 30 \\
X3 & Pressure Column. & $39.5 \mathrm{~atm}$ & 0.5 \\
\hline
\end{tabular}


Table 2. Application of factorial design (Three factors).

\begin{tabular}{cccc}
\hline Experience & Factor $\mathbf{1}$ & Factor 2 & Factor 3 \\
\hline 1 & -1 & -1 & -1 \\
2 & +1 & -1 & -1 \\
3 & -1 & +1 & -1 \\
4 & +1 & +1 & -1 \\
5 & -1 & -1 & +1 \\
6 & +1 & -1 & +1 \\
7 & -1 & +1 & +1 \\
8 & +1 & +1 & +1 \\
\hline
\end{tabular}

Table 3. The values of the factors studied with no coding unit.

\begin{tabular}{cccc}
\hline $\mathbf{N}^{\circ}$ Test & Factor $\mathbf{1}$ & Factor $\mathbf{2}$ & Factor $\mathbf{3}$ \\
\hline 1 & 70 & 70 & 39 \\
2 & 130 & 70 & 39 \\
3 & 70 & 130 & 39 \\
4 & 130 & 130 & 39 \\
5 & 70 & 70 & 40 \\
6 & 130 & 70 & 40 \\
7 & 70 & 130 & 40 \\
8 & 130 & 130 & 40 \\
\hline
\end{tabular}

Table 4. The results obtained (response) after the application of the experimental design.

\begin{tabular}{cccccc}
\hline ECH & $\begin{array}{c}\text { Oven } \\
\text { Temperature } \\
\left({ }^{\circ} \mathbf{C}\right)\end{array}$ & $\begin{array}{c}\text { Intel Back } \\
\text { Temperature } \\
\left({ }^{\circ} \mathbf{C}\right)\end{array}$ & $\begin{array}{c}\text { Pressure } \\
\text { Column (atm) }\end{array}$ & RT & $\begin{array}{c}\text { [Diacetyl] } \\
\mu \mathrm{g} / \mathrm{L}\end{array}$ \\
\hline $\begin{array}{c}\text { Reference } \\
\text { Sample }\end{array}$ & 70 & 150 & 39 & 5.6 & 16.5 \\
\hline 1 & 70 & 70 & 39 & 5.602 & 17.06133 \\
2 & 13 & 70 & 39 & ND $(5.58)$ & 0 \\
3 & 70 & 130 & 39 & 5.605 & 16.346 \\
4 & 130 & 130 & 39 & ND & ND \\
5 & 70 & 70 & 40 & 5.459 & 16.708 \\
6 & 130 & 70 & 40 & ND & 0 \\
7 & 70 & 130 & 40 & $(5.462)$ & 16.70835 \\
8 & 130 & 130 & 40 & ND & ND \\
\hline
\end{tabular}

ND: Not detected.

\subsection{Interpretation of Analysis in Various Fermentation Conditions}

During classical fermentation the first peak of the diacetyl concentration normally appears early. The concentration of diacetyl is then reduced when the yeast assimilates diacetyl and converts it enzymatically into acetone, which in turn is then metabolized. Diacetyl is thought to be a by-product of amino acid biosynthesis involving a relationship between amino acid biosynthesis and the formation of acetolactate, the diacetyl precursor. The second peak of diacetyl is explained by the decrease in fermentable sugars and a maximum activity of the yeast, hence a concentration of diacetyl proportional to the multiplication of the yeast and the degradation of fermentable sugars (production associated with growth). However, problems arise when continuous metabolic fluctuations lead to late production of diacetyl in amounts that create a 3rd peak which may be due to the presence of a high concentration of diacetyl in the beer wort. The higher levels of diacetyl resulting from late fermentation cannot be reduced below its gustatory threshold in the allotted time. 
The total concentration of diacetyl in the beer at a given time during and after fermentation results from the combination of the rate of formation of $\alpha$-acetolactate, its rate of conversion, and the rate of reduction of diacetyl to 2,3-butanediol and acetone. Any latency of high diacetyl concentration resulting from late fermentation cannot be reduced until the beer undergoes further treatment, which may require prolonged maturation or other treatments or remedial measures to bring the final diacetyl concentration within the target specification of the desired final product (0-40) microgram per liter (Figure 1).

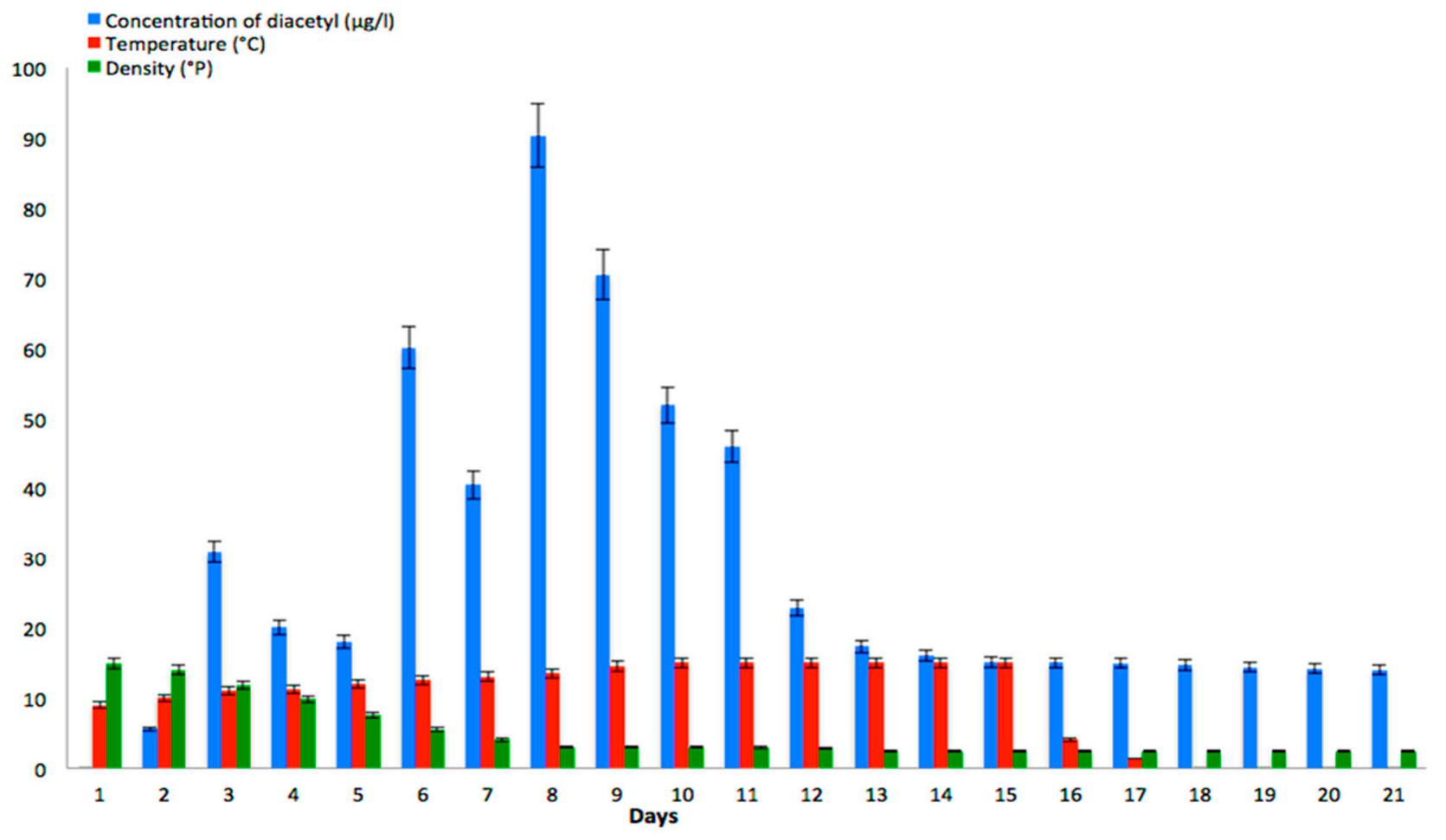

Figure 1. Monitoring of diacetyl concentration during classical fermentation.

In the process of stopping fermentation the wort has been cooled to about $20^{\circ} \mathrm{C}$, is stripped under pressure to avoid foam production. This method produces a good quality beer with less than $0.2 \%$ alcohol by volume, but it requires precise analytical control. The yeast mass and alcohol content must be monitored every $8 \mathrm{~h}$. In Super high gravity production, starting at $17^{\circ} \mathrm{P}, 6.5^{\circ} \mathrm{P}$ is obtained after centrifugation at about $0.4{ }^{\circ} \mathrm{C}$ and dilution, before or after final filtration, with desalted water to reach the desired alcohol and saccharometric level. When producing non-alcoholic beers by stopping fermentation, the main objective is to reduce the impression of bad taste or to limit it from the beginning and for diacetyl concentrations between 11 and $12 \mu \mathrm{g} / \mathrm{L}$ (Figure 2).

Fermentation coupled with the thermal process represents the easiest method to have an alcohol-free beer, the application of heating between $35^{\circ} \mathrm{C}$ and $60^{\circ} \mathrm{C}$ until boiling results in the elimination of alcohol and other volatile substances such as esters and higher alcohols consequently increasing the turbidity of the 0.3 to 2.5 IBC (Table 5) [34].

The final beer product under different conditions was analyzed by GC to identify its aroma compounds. The results show that the concentration of diacetyl also increases between the stop of fermentation and the release of the final product, with the concentration of diacetyl at the last day of fermentation is equal to $12 \mu \mathrm{g} / \mathrm{L}$ this concentration increases up to $160 \mu \mathrm{g} / \mathrm{L}$ in the final product. This difference requires control of factors such as oxygen level and temperature between the fermentation stage and the release of the final product (Table 6, Figure 3). 


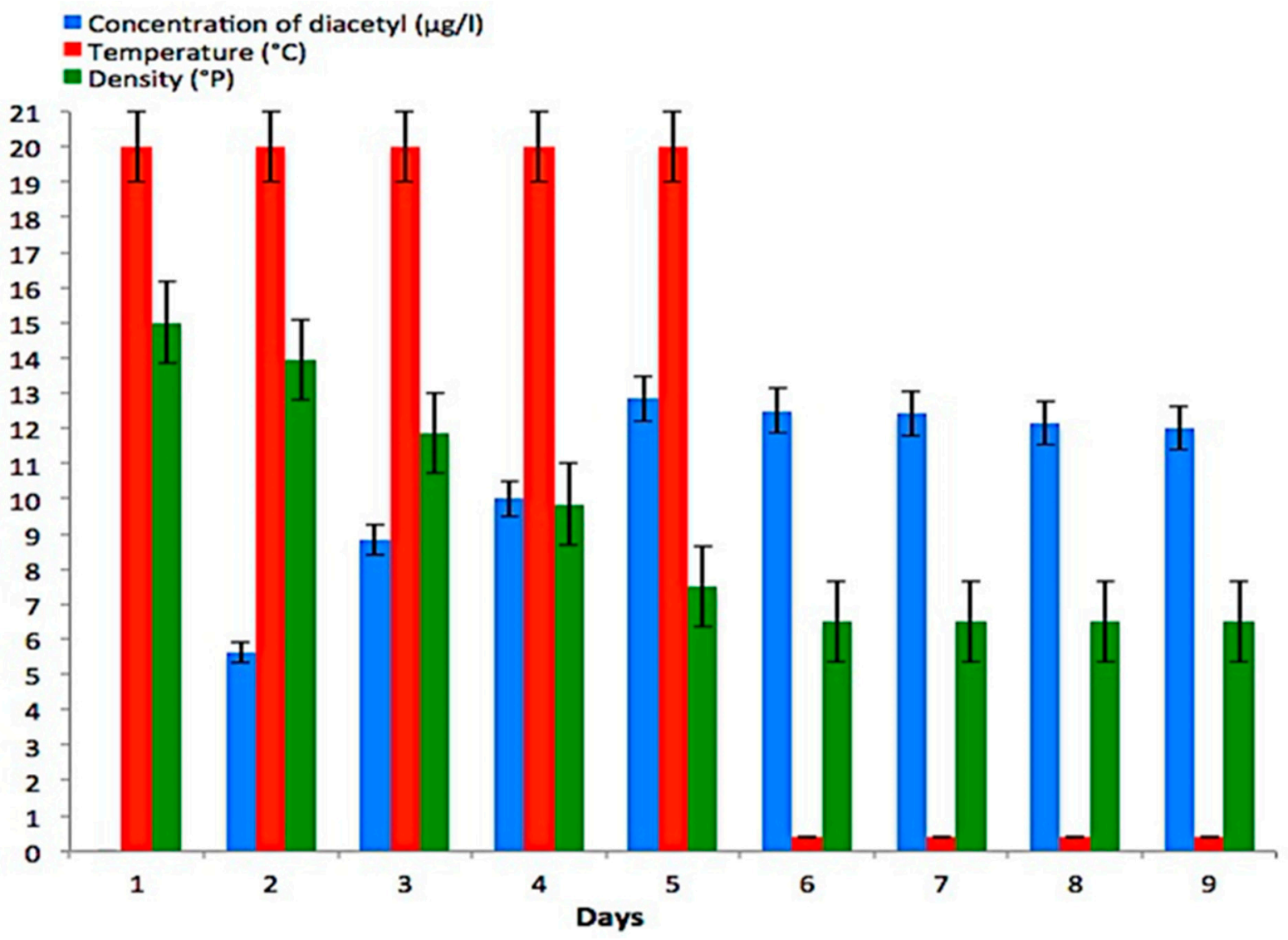

Figure 2. Monitoring of diacetyl concentration during stopping fermentation.

Table 5. Aromatic compounds and turbidity of the final product of alcoholic and de-alcoholized beer in various fermentation conditions determined by GC.

\begin{tabular}{lccc}
\hline \multicolumn{1}{c}{ Detected Compounds } & $\begin{array}{c}\text { Final Product of Beer by } \\
\text { Using Classical } \\
\text { Fermentation }\end{array}$ & $\begin{array}{c}\text { Final Product of Non-Alcoholic } \\
\text { Beer by Using Stopping } \\
\text { Fermentation }\end{array}$ & $\begin{array}{c}\text { Final Product of } \\
\text { Non-Alcoholic Beer by } \\
\text { Using Thermal Process }\end{array}$ \\
\hline Ethanol (vol\%) & 5.2 & 0.4 & 0.02 \\
Acetaldehyde (mg/L) & 7.2 & 8.5 & 4.0 \\
Propanol (mg/L) & 22 & 9 & Not detected \\
Ethyl acetate (mg/L) & 20.2 & 3.4 & Not detected \\
Isobutanol (mg/L) & 21.4 & 3.2 & Not detected \\
Isoamyl acetate (mg/L) & 2.35 & 0.12 & Not detected \\
3-methylbutanol (mg/L) & 60.1 & 1.25 & 0.25 \\
2-methylbutanol (mg/L) & 20.2 & Traces & Traces \\
Phenylethanol (mg/L) & 33.11 & 35.1 & 38.5 \\
Furfuryl alcohol (mg/L) & 3.11 & 2.6 & 2.411 \\
Diacetyl (mg/L) & 0.16 & 0.36 & 0.07 \\
DMS ( $\mu$ g/L) & 22 & 45 & Not detected \\
Turbidity (IBC) & 0.35 & 1.5 & 2.5 \\
\hline
\end{tabular}

At the end of fermentation, oxygen is eliminated from the milieu because it is consumed during the respiration phase of the yeast. The remaining quantity is used during fermentation because it is essential in the biosynthesis of sterols, which are essential molecules for the maintenance of cell walls and give the yeast a high rate of viability.

After filtration process, the oxygen concentration is higher than measured in the holding tank (after the end of fermentation). This concentration decreases over time. This occurs due to removing the air bubbles formed at the beginning of the filtration process. 
The water used in the preparation of the filtration layers contains a significant amount of oxygen.

Table 6. Aromatic compounds of a final product of beer under classical fermentation.

\begin{tabular}{cccc}
\hline Peak & Compound & Retention Time (min) & Amount \\
\hline 1 & Acetaldehyde $(\mathrm{mg} / \mathrm{L})$ & 4.211 & 7.29 \\
2 & DMS $(\mu \mathrm{L} / \mathrm{L})$ & 4.508 & 21.989 \\
3 & Ethyl acetate $(\mathrm{mg} / \mathrm{L})$ & 5.777 & 20.838 \\
4 & Methanol $(\mathrm{mg} / \mathrm{L})$ & 5.928 & 2.210 \\
5 & n-Propanol $(\mathrm{mg} / \mathrm{L})$ & 9.412 & 13.546 \\
6 & Iso-Butanol $(\mathrm{mg} / \mathrm{L})$ & 11.349 & 21.439 \\
7 & Isoamyl acetate $(\mathrm{mg} / \mathrm{L})$ & 12.748 & 2.456 \\
8 & Heptanone $(\mathrm{mg} / \mathrm{L})$ & 13.035 & 1.000 \\
9 & Butanol $(\mathrm{mg} / \mathrm{L})$ & 13.750 & 1.000 \\
10 & Amyl alcohols $(\mathrm{mg} / \mathrm{L})$ & 16.760 & 73.130 \\
\hline
\end{tabular}

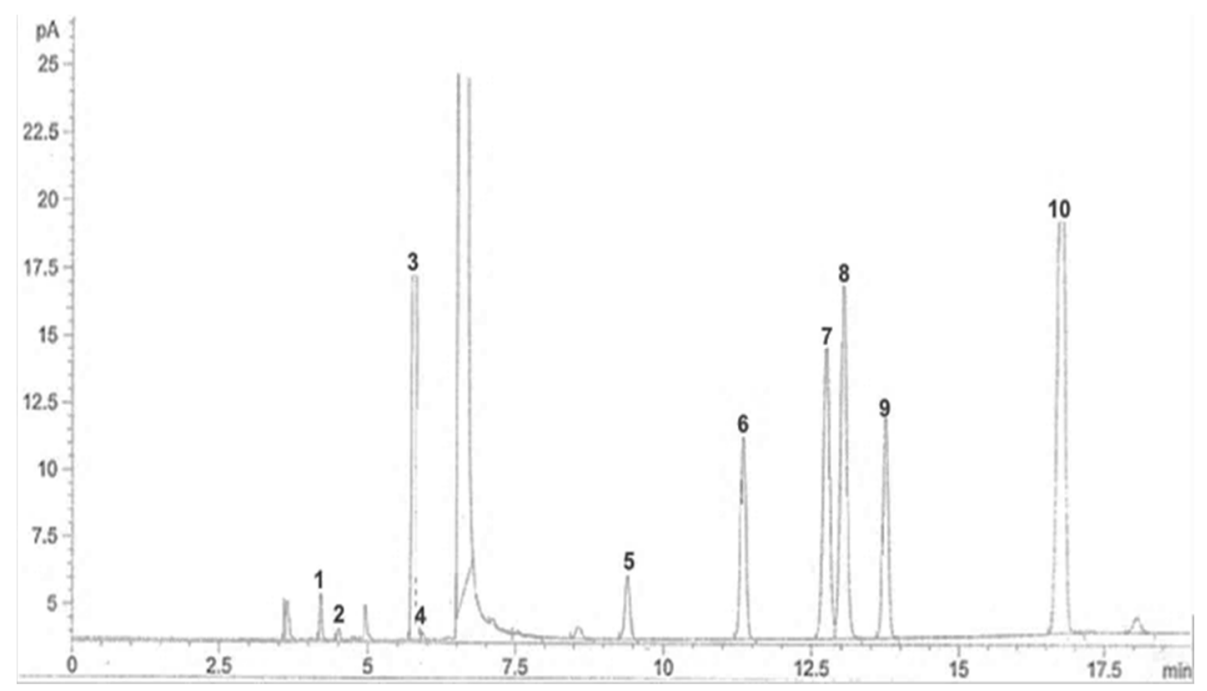

Figure 3. Chromatogram of a beer sample on a DBWAX column.

At the filler inlet, the oxygen concentration decreases proportionally with increasing temperature, this is due to the fact that oxygen is less soluble at higher temperatures. (HENRY's law), (Figure 4).

In general, the dissolution of oxygen in beer is high if the temperature is low and the pressure is high. The length of the pipes increases the risk of oxygen saturation in the beer. Aeration at the beginning of fermentation with less than $10 \mathrm{~g} / \mathrm{L}$ is not a potential risk of oxidation since the yeast consumes the remaining oxygen during secondary fermentation. Controlling the pressure stability of clear beer tanks should be carried out to optimize the rate of oxygen removal by carbon dioxide.

The FTIR spectra analysis of the beer, shows the presence of -NH bonds of amines between $3000-3400 \mathrm{~cm}^{-1}$ as well as primary and secondary amine bonds between 2800 $3000 \mathrm{~cm}^{-1}, \mathrm{C}=\mathrm{O}$ bonds of amides and aromatic ketones, $\mathrm{C}-\mathrm{O}$ bonds of esters between $1300-1450 \mathrm{~cm}^{-1}$, C-O bonds of primary and secondary alcohols between $1040-1090 \mathrm{~cm}^{-1}$ and finally Ar-C bonds of aromatics between $850-890 \mathrm{~cm}^{-1}$.

The total concentration of diacetyl in the beer must during and after fermentation results from a combination of the rate of formation of $\alpha$-acetolactate, its rate of conversion, and the rate of reduction of diacetyl to 2,3-butanediol and acetone. Any latency of removed diacetyl concentration resulting from late fermentation production cannot be reduced until the beer undergoes further processing, which may require prolonged maturation or other processing or corrective measures to bring the final diacetyl concentration within 
the desired product target specification (0-40) micrograms per liter. This increase due to bacterial contamination reactions and the presence of oxygen which oxidizes ketones and alcohols is confirmed by Figure 5 which indicates that the oxygen level decreases as a function of time in the beer in parallel with other parameters such as temperature.

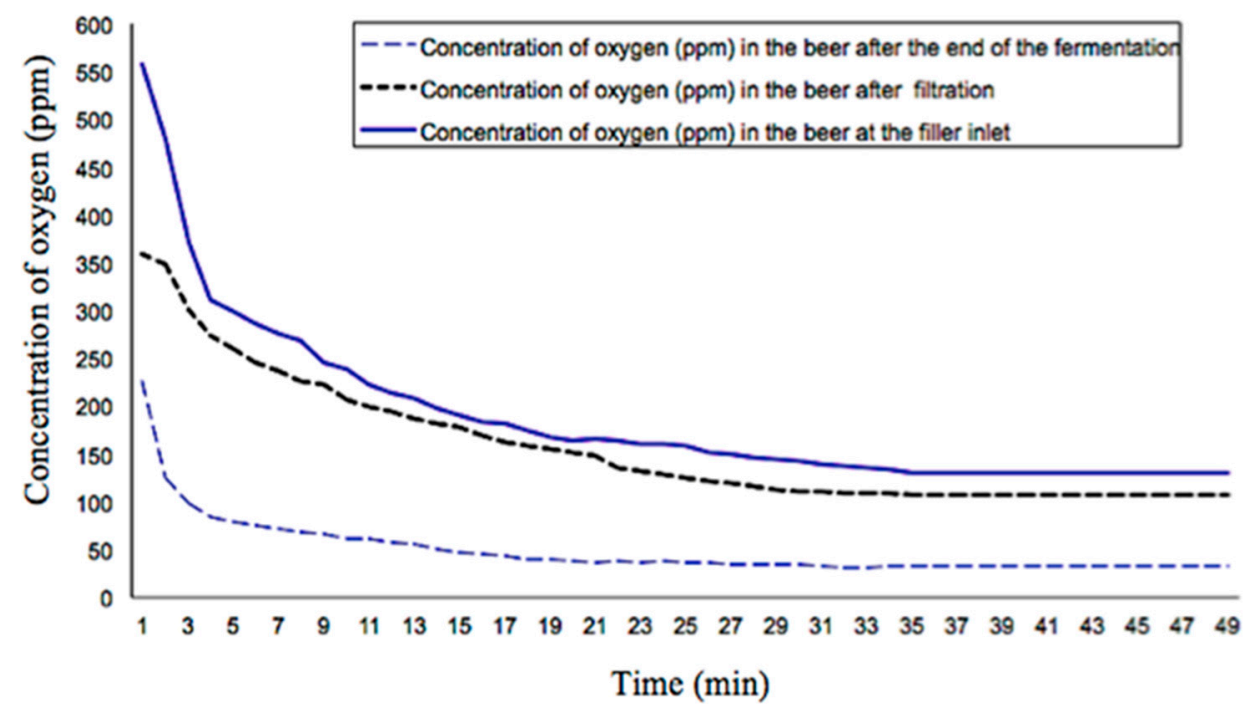

Figure 4. Monitoring of oxygen concentration during the process of beer production.

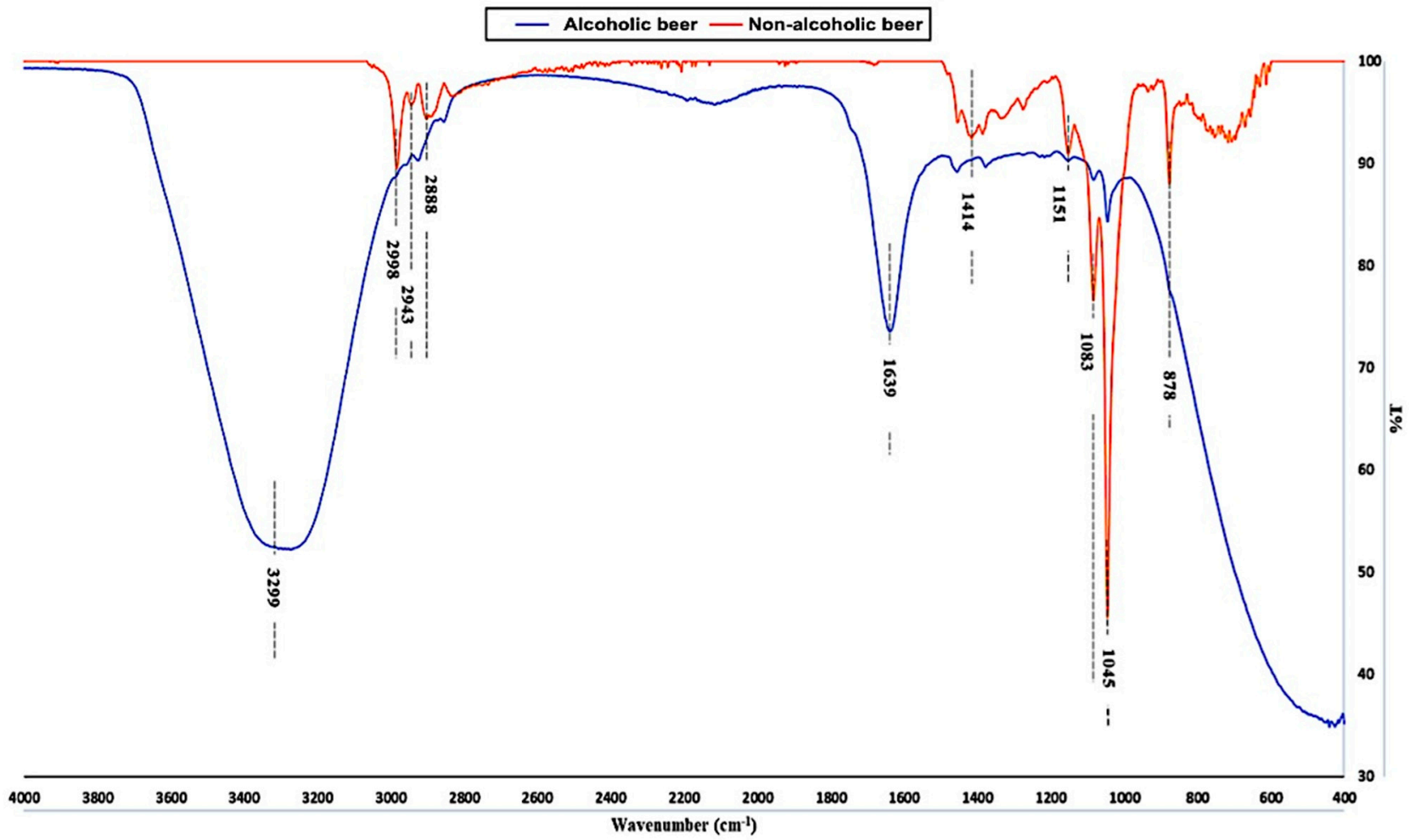

Figure 5. FTIR (Fourier transform infrared spectroscopy) spectra of alcoholic and non-alcoholic beer.

\subsection{Interpretation of Spectroscopic Analysis}

According to the mean values of the analyzed beer types presented in Figure 6, hopped wort (HW) sample contained flavonoids and total phenolic in higher concentrations (28 $\mathrm{mg} \mathrm{CE} 100 \mathrm{~mL}^{-1}, 65 \mathrm{mg} \mathrm{GAE} 100 \mathrm{~mL}^{-1}$, respectively) than sweet wort (SW), which is reflected in their very high antioxidant activity with a free radical inhibition capacity of $13.41 \%$, Figure $6 \mathrm{a}$. 

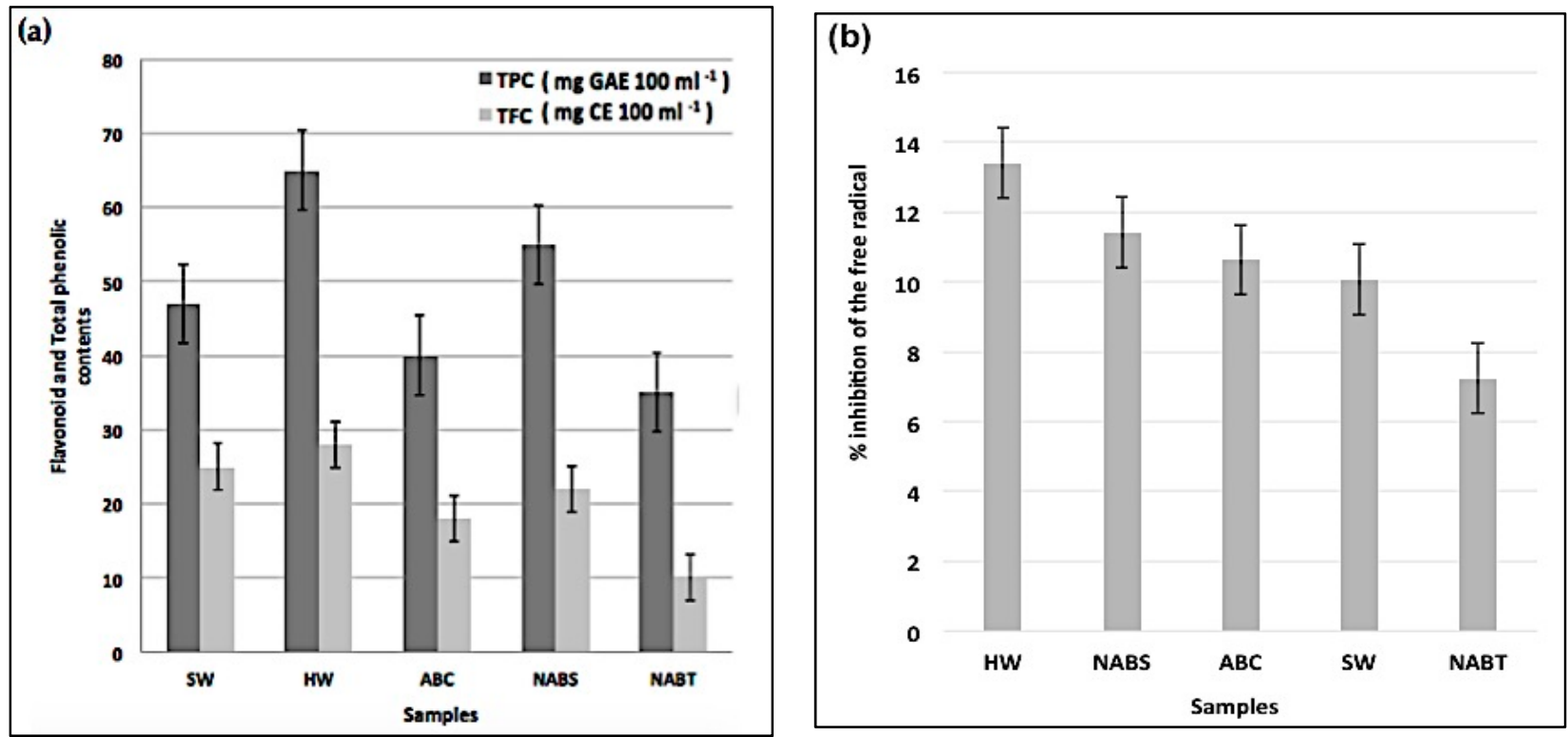

Figure 6. Flavonoid, total Phenolic Contents (a) and percentage inhibition of free radical scavenging activity (b) of the analyzed samples.

After different fermentation processes, the highest concentration of flavonoids and total phenolic contents (22 mg CE $100 \mathrm{~mL}^{-1}, 55.12 \mathrm{mg} \mathrm{GAE} 100 \mathrm{~mL}^{-1}$, respectively) was observed in the non-alcoholic stopping fermentation beer (NABS), with a higher free radical scavenging capacity than alcoholic beer by using classical fermentation $(\mathrm{ABC})$ and nonalcoholic beer by using thermal process (NABT). The lowest concentration of flavonoids and total phenolic contents (10.01 mg CE $100 \mathrm{~mL}^{-1}, 35.1 \mathrm{mg} \mathrm{GAE} 100 \mathrm{~mL}^{-1}$, respectively) could be observed in non-alcoholic beer by using thermal process (NABT) Figure $6 \mathrm{~b}$.

The beer filtration process reduces the content of phenolic compounds, as well as the antioxidant activities of the wort. With the higher consumption of diatomite, a high concentration of iron ions is introduced, which decreases the scavenging rate of DPPH, During the cooling phase, the spontaneous adsorption of phenolic compounds and melanoidins on the wort lees and polymerization lead to the decrease of TPC in beer [35-37].

\section{Conclusions}

Analytical chemistry is playing an increasingly important role in beer flavor analysis, chemical analysis of beer is essential and is widely used in various research areas related to beer production. Furthermore, beer is a complex alcoholic beverage containing both volatile and non-volatile components. The validation of a method to control and monitor the concentration of diacetyl in the different stages of alcoholic and non-alcoholic beer production to understand how to maintain the balance between the different types of flavors.

The application of spectrophotometric analysis is essential in the evaluation of the antioxidant quality in the final product. The antioxidant potential of beer depends not only on the quality of the raw materials, but also on the technological process.

Author Contributions: Conceptualization, F.E.M. and J.B.; methodology, F.E.M. and H.E.F.; validation, F.E.M. and H.E.F. and B.B.; investigation, F.E.M. and H.E.F. and B.B.; resources, J.B.; writingoriginal draft preparation, F.E.M.; writing - review and editing, F.C., M.P.L. and J.C.G.E.d.S.; supervision, F.C. and J.B.; project administration, J.B. and J.C.G.E.d.S. All authors have read and agreed to the published version of the manuscript.

Funding: This research received no external funding.

Institutional Review Board Statement: Not applicable. 
Informed Consent Statement: Not applicable.

Data Availability Statement: Not applicable.

Conflicts of Interest: The authors declare no conflict of interest.

\section{References}

1. Bamforth, C.W. Current perspectives on the role of enzymes in brewing. J. Cereal Sci. 2009, 50, 353-357. [CrossRef]

2. Olaniran, A.O.; Hiralal, L.; Mokoena, M.P.; Pillay, B. Flavour-active volatile compounds in beer: Production, regulation, and control. J. Inst. Brew. 2017, 123, 13-23.

3. Guido, L.F.; Rodrigues, P.G.; Rodrigues, J.A.; Gonçalves, C.R.; Barros, A.A. The impact of the physiological condition of the pitching yeast on beer flavor stability: An industrial approach. Food Chem. 2004, 87, 187-193. [CrossRef]

4. Pires, E.J.; Teixeira, J.A.; Branyik, T.; Vicente, A.A. Yeast: The soul of beer's aroma a review of flavor-Active esters and higher alcohols produced by the brewing yeast. Appl. Microbiol. Biotechnol. 2014, 98, 1937-1949. [CrossRef] [PubMed]

5. Kunze, W. Technology Brewing and Malting; VLB Berlin: Berlin, Germany, 1996.

6. Piddocke, M.; Olsson, L. Beer Brewing, Applications of Metabolic Engineering; John Wiley \& Sons Inc.: Hoboken, NJ, USA, 2010.

7. Saerens, S.M.G.; Duong, C.T.; Nevoigt, E. Genetic improvement of brewer's yeast: Current state, perspectives, and limits. Appl. Microbiol. Biotechnol. 2010, 86, 1195-1212. [CrossRef] [PubMed]

8. Kopsahelis, N.; Kanellaki, M.; Bekatorou, A. Low temperature brewing using cells immobilized on brewer's spent grains. Food Chem. 2007, 104, 480-488. [CrossRef]

9. Witrick, K.; Pitts, E.R.; O'Keefe, S.F. Analysis of Lambic Beer Volatiles during Aging Using Gas Chromatography-Mass Spectrometry (GCMS) and Gas Chromatography-Olfactometry (GCO). Beverages 2020, 6, 31. [CrossRef]

10. Bekatorou, A.; Soupioni, M.J.; Koutinas, A.; Kanellaki, M. Low-temperature brewing by freeze-dried immobilized cells. Appl. Biochem. Biotechnol. 2002, 97, 105-122. [CrossRef]

11. McKernan, L.T.; McKernan, L.T.; Kreiss, K.; Hubbs, A.; Park, R.; Dankovic, D.; Dunn, K.H.; Parker, J.; Fedan, K.; Streicher, R.; et al. Criteria for a Recommended Standard: Occupational Exposure to Diacetyl and 2,3-Pentanedione; Publication No. 2016-111; National Institute for Occupational Safety and Health: Cincinnati, OH, USA, 2016.

12. Kreiss, K.; Gomaa, A.; Kullman, G.; Fedan, K.; Simoes, E.J.; Enright, P.L. Clinical bronchiolitis obliterans in workers at a microwave-popcorn plant. N. Engl. J. Med. 2002, 347, 330-338. [CrossRef]

13. Curwin, B.D.; Deddens, J.A.; McKernan, L.T. Flavoring exposure in food manufacturing. J. Expo. Sci. Environ. Epidemiol. 2014, 25, 121. [CrossRef]

14. Klager, S.; Vallarino, J.; MacNaughton, P.; Christiani, D.C.; Lu, Q.; Allen, J.G. Flavoring chemicals and aldehydes in E-cigarette emissions. Environ. Sci. Technol. 2017, 51, 10806-10813. [CrossRef]

15. Allen, J.G.; Flanigan, S.S.; LeBlanc, M.; Vallarino, J.; Mac Naughton, P.; Stewart, J.H.; Christiani, D.C. Flavoring chemicals in E-cigarettes: Diacetyl, 2,3-pentanedione, and acetoin in a sample of 51 products, including fruit-, candy-, and cocktail- flavored E-cigarettes. Environ. Health Perspect. 2016, 124, 733-739. [CrossRef] [PubMed]

16. Kucharczyk, K.; Żyła, K.; Tuszyński, T. Simultaneous Optimization of Acetaldehyde and DMS Concentrations for Better Sensory Quality of Beer Fermented on an Industrial Scale. Foods 2020, 9, 1043. [CrossRef] [PubMed]

17. Kelly, F.L.; Sun, J.; Fischer, B.M.; Voynow, J.A.; Kummarapurugu, A.B.; Zhang, H.L.; Nugent, J.L.; Beasley, R.F.; Martinu, T.; Gwinn, W.M.; et al. Diacetyl induces amphiregulin shedding in pulmonary epithelial cells and in experimental bronchiolitis obliterans. Am. J. Respir. Cell. Mol. Biol. 2014, 51, 568-574. [CrossRef]

18. Kelly, F.L.; Weinberg, K.E.; Nagler, A.E.; Nixon, A.B.; Star, M.D.; Todd, J.L.; Brass, D.M.; Palmer, S.M. EGFR-Dependent IL8 Production by Airway Epithelial Cells After Exposure to the Food Flavoring Chemical 2,3-Butanedione. Toxicol. Sci. 2019, 169, 534-542. [CrossRef]

19. Gerloff, J.; Sundar, I.K.; Freter, R.; Sekera, E.R.; Friedman, A.E.; Robinson, R.; Pagano, T.; Rahman, I. Inflammatory response and barrier dysfunction by different e-cigarette flavoring chemicals identified by gas chromatography-mass spectrometry in e-liquids and e-vapors on human lung epithelial cells and fibroblasts. Appl. Vitr. Toxicol. 2017, 3, 28-40. [CrossRef] [PubMed]

20. Muthumalage, T.; Prinz, M.; Ansah, K.O.; Gerloff, J.; Sundar, I.K.; Rahman, I. Inflammatory and oxidative responses induced by exposure to commonly used ecigarette flavoring chemicals and flavored e-liquids without nicotine. Front. Physiol. 2017, 8, 1130. [CrossRef] [PubMed]

21. Kovacic, P.; Cooksy, A.L. Electron transfer as a potential cause of diacetyl toxicity in popcorn lung disease. Rev. Environ. Contam. Toxicol. 2010, 204, 133-148.

22. Gwinn, W.M.; Flake, G.P.; Bousquet, R.W.; Taylor, G.J.; Morgan, D.L. Airway injury in an in vitro human epithelium-fibroblast model of diacetyl vapor exposure: Diacetyl-induced basal/suprabasal spongiosis. Inhal. Toxicol. 2017, 29, 310-321. [CrossRef]

23. Hubbs, A.F.; Fluharty, K.L.; Edwards, R.J.; Barnabei, J.L.; Grantham, J.T.; Palmer, S.M.; Kelly, F.; Sargent, L.M.; Reynolds, S.H.; Mercer, R.R.; et al. Accumulation of ubiquitin and sequestosome-1 implicate protein damage in diacetyl-induced cytotoxicity. Am. J. Pathol. 2016, 186, 2887-2908. [CrossRef]

24. Akpinar-Elci, M.; Travis, W.D.; Lynch, D.A.; Kreiss, K. Bronchiolitis obliterans syndrome in popcorn production plant workers. Eur. Respir. J. 2004, 24, 298-302. [CrossRef] [PubMed] 
25. Van Rooy, F.G.; Rooyackers, J.M.; Prokop, M.; Houba, R.; Smit, L.A.; Heederik, D.J. Bronchiolitis obliterans syndrome in chemical workers producing diacetyl for food flavorings. Am. J. Respir. Crit. Care Med. 2007, 176, 498-504. [CrossRef]

26. Van Rooy, F.G.; Smit, L.A.; Houba, R.; Zaat, V.A.; Rooyackers, J.M.; Heederik, D.J. A cross-sectional study of lung function and respiratory symptoms among chemical workers producing diacetyl for food flavourings. Occup. Environ. Med. 2009, 66, 105-110. [CrossRef] [PubMed]

27. Terazawa, K.; Mizukami, K.B.; Takatori, T. Fatality due to inhalation of dimethyl sulfide in a confined space: A case report and animal experiments. Int. J. Legal Med. 1991, 104, 141-144. [CrossRef] [PubMed]

28. Montanari, L.; Marconi, O.; Mayer, H.; Fantozzi, P. Production of Alcohol-Free Beer. In Beer in Health and Disease Prevention; Academic Press: Cambridge, MA, USA, 2009; pp. 61-75. [CrossRef]

29. Goupy, J. Introduction aux Plans D'expériences; Dunod: Paris, France, 2001; p. 303.

30. Poirier, J. Analyse de la variance et de la régression. Plans d'expériences Techniques de l'ingénieur. Traité Mesures et contrôle. Ref. Tech. Sci. Expert. 1993, 260, 1-23.

31. Singleton, V.L.; Orthofer, R.; Lamuela-Raventos, M. Analysis of Total Phenols and Other Oxidation Substrates and Antioxidants by Means of Folin-Ciocalteu Reagent. Methods Enzymol. 1999, 299, 152-178.

32. Kim, D.O.; Jeong, S.W.; Lee, C.Y. Antioxidant Capacity of Phenolic Phytochemicals from Various Cultivars of Plums. Food Chem. 2003, 81, 321-326. [CrossRef]

33. Benkeblia, N. Free radical scavenging capacity and antioxidant properties of some selected onions (Aliium cepa L.) and garlic (Aliium sativum L.) extracts. Braz. Arch. Biol. Technol. 2005, 48, 1-8. [CrossRef]

34. Zufall, C.; Wackerbauer, K. Monatsschrift Process engineering parameters for the deaIcoholisation of beer by means of falling film evaporation and its influence on beer quality. Mon. Fur Brauwiss. 2000, 53, 124-137.

35. Malakar, S.; Sanjib, K.P.; Jolvis Pou, K.R. Antioxidant activity of polyphenols extracted from hop used in craft beer. In Biotechnological Progress and Beverage Consumption; Grumezescu, A., Holban, A.M., Eds.; Academic Press: Salt Lake City, UT, USA, 2020; pp. 283-310. [CrossRef]

36. Koren, D.; Kun, S.; Vecseri, B.H.; Kun-Farkas, G. Study of antioxidant activity during the malting and brewing process. J. Food Sci. Technol. 2019, 56, 3801-3809. [CrossRef]

37. Ambra, R.; Pastore, G.; Lucchetti, S. The Role of Bioactive Phenolic Compounds on the Impact of Beer on Health. Molecules 2021, 26, 486. [CrossRef] [PubMed] 